Article

\title{
Feasibility of the Fintech Industry as an Innovation Platform for Sustainable Economic Growth in Korea
}

\author{
Yong Jae Shin ${ }^{1}$ and Yongrok Choi ${ }^{2, *(D)}$ \\ 1 Department of Management Information Systems, Sahmyook University, 815, Hwarang-ro, Nowon-gu, \\ Seoul 01795, Korea; yjshin@syu.ac.kr \\ 2 Department of International Trade, Inha University, 100 Inha-ro, Michuhol-gu, Incheon 22212, Korea \\ * Correspondence: yrchoi@inha.ac.kr
}

Received: 17 August 2019; Accepted: 23 September 2019; Published: 27 September 2019

\begin{abstract}
This paper examines the feasibility of fintech as a platform for sustainable economic growth and as a prompter of the fourth industrial revolution. To analyze the role of fintech in the national economy, we first broaden its definition and compare its economic performance using three methodologies-Demand-driven model, Supply-driven model and industry linkage effect in interindustry analysis. We find that the fintech industry has a stronger effect on production inducement. Regarding industry linkage effects, fintech ranked the top in all 31 industries for the forward linkage effect and 22 for the background linkage effect-much higher than the traditional financial industry. This implies that the fintech industry is effective as the intermediate good with national demand as well as the final good. Particularly, this industry plays the roles of intermediate and final goods across almost all industries. That is, fintech could better promote overall national economic performance as a platform industry. Because most businesses within the fintech industry depend on innovation through the integration of finance and information technology, we find that fintech can feasibly prompt the fourth industrial revolution. Nonetheless, this industry is characterized by excessive regulations in Korea, indicating the need for negative regulation for new, innovative businesses within the fintech industry that would critically emphasize innovativeness for inclusive, sustainable economic growth.
\end{abstract}

Keywords: fintech; sustainable growth; innovation; input-output analysis; exogenous specification

\section{Introduction}

The fourth industrial revolution, popularly characterized by artificial intelligence, Internet of Things and robotics, is a platform industry that increases the competitiveness of all industries through value-added and qualitatively differentiated services [1]. This revolution expanded to financial technology or fintech, creating a novel business model based on financial services provided through critical technological innovations.

Fintech is innovative technology that aims to operate traditional financial services using computer programs and information technology (IT) [2]. This emerging industry incorporates technology to enhance both financial activities as well as promote services such as smart financial consulting [3]. Lee and Shin (2018) emphasized the role of fintech as a prompter for innovation in the financial industry and as a leader of the sharing economy [4]. Philippon (2016) also noted that fintech could induce business revolution via digital revolution by developing innovative ways to provide products and services and thus mitigating or eliminating, impediments common in traditional industries [5].

This contemporary ecosystem was created through diverse innovations of new fintech businesses, fintech developers, smart financial consumers, rapidly evolving traditional financial institutions and even governments. Through IT, artificial intelligence and Internet of Things technologies, fintech is 
transforming core aspects (e.g., payment, insurance, saving deposits and loan services) of financial industries into a newer, integrated, yet diverse, service industry $[4,6]$.

According to a global report [7], fintech industry consists of payments (84 percent), fund transfers (68 percent), personal finance (60 percent), personal loans (56 percent), traditional deposits/savings accounts ( 49 percent), insurance ( 38 percent) and wealth management services ( 38 percent) [7]. The fintech industry complements not only the traditional financial services but it also creates unique business services. According to KPMG (2019), the fintech industry has grown more than six times-from US $\$ 18.9$ bn in 2013 to US $\$ 111.8$ bn—for just six years in the global market [8]. This industry comprises numerous business models and it is one of the most rapidly growing businesses in the world.

The fintech industry has huge potential, especially illustrated by the so-called 'unicorn companies' with outstanding performance. According to CBINSIGHTS (2019), unicorn companies' global market value exceeds US\$ 1 bn in such a short period. As expected, the U.S. ranks first with 24 fintech unicorn companies led by the Credit Kama (US\$ 48 bn). Asia has nine successful unicorn companies, with six companies in China, two in India and one in South Korea [6]. The distribution of these unicorn companies is scattered, implying that the fintech industry could become a new global norm in all economic activities regardless of the level of economic development.

Despite the general unawareness of financial consumers, fintech is already deeply rooted in the Korean economy. In 2017, 84 percent of financial consumers used fintech as their payment service, whereas 38 percent used wealth management services for their portfolio [7]. This rapid adoption of fintech services has allowed the industry to grow by over six times: from US\$ 18.9 bn in 2013 to US $\$ 111.8$ bn in 2018 [8]. Irrespective of challenges such as an encumbering regulatory system and risks associated with any new industry, the fintech industry is experiencing strong growth owing to customized, consumer-oriented innovations for the smart consumer $[9,10]$.

Fintech is also an engine for sustainable development of developing economies. This is true especially for Korea because fintech is a platform for innovations in the financial industry and a prompter for transformation into an advanced economy equipped to cope with the fourth industrial revolution $[10,11]$. Fintech could provide new financial services as well as diverse on-demand services adjacent to the field of finance [12]. The function of timelines and convenience of fintech are crucial when creating diverse new businesses based on on-demand fulfillment of consumer demands $[13,14]$. Especially, peer-to-peer (P2P) crowdfunding supported by fintech has opened new avenues for consumers, who can now bypass traditional financial institutions. This phenomenon might lead to diverse, new financial businesses with their own sustainable ecosystem [15-22].

There is abundant research on the fintech industry. When the fintech industry was in its initial stages, most research focused on the definition of fintech services and their functional role in the financial sector [16-19]. They argued the different characters of this industry from the traditional financial industry because of its unique ecosystem, though fintech would eventually evolve to broaden the scope of services in the traditional financial industry $[5,9,10,12,16,20,21]$. Also, several papers have revealed that the fintech industry's ecosystem and business model with distinct characteristics from the existing financial industry $[1,4,22]$. From the customer's perspective, most analyses are focused on the user's intention to consume fintech products and services; this includes determining major factors of user intention, such as usefulness and ease of use [23-26]. In economic perspective, Porras-Gonzalez et al. (2019) introduced the positive impacts and limitations of blockchain technology on the global economy [27]. As such, fintech is an industry that has brought innovation in the financial industry. It is expected to contribute to economic sustainability as an industry having distinct characteristics from the existing financial industry. However, many of the previous studies have focused on aspects of innovative tools in the financial industry but simply concluded that they would have a positive impact on the economic system. Therefore, it is necessary to find the quantitative evidence of the economic impact between the fintech industry and the existing financial industry on the national economy. This research objective is important to identify the fintech industry as not only an innovation tool for the financial industry but also an platform for the level-up of all the traditional economic system. 
In this study, we seek to answer the critical questions: Can the fintech industry play a role as an innovation platform industry at the national economic level? To answer this, the following detailed questions should be answered: First, is the fintech industry different from the traditional financial industry in terms of amount and scope of impact on the national economy? Second, what role does the fintech industry play in the national economic ecosystem?

Therefore, the purpose of this study is to investigate whether the fintech industry can play a role of an innovation platform at the national level, which will be measured quantitatively by the direct and indirect economic impacts of the fintech industry. To analyze this in national equilibrium model, the study uses demand driven model (DDM), supply driven model (SDM) and industry linkage analysis. Through these approaches, this study shall prove that the fintech industry triggered creative destruction in the financial industry by the economic ripple effects.

\section{Literature Review and Theoretical Background}

\subsection{Conceptual Characteristics of Fintech}

Fintech refers to technology-enabled financial solutions. However, it is not only confined to sectors such as financing or business models such as P2P lending but also covers the entire scope of services and products traditionally provided by the financial services industry [8]. Kim et al. (2016) defined fintech as a service sector that uses mobile-centered IT technology to enhance the efficiency of the financial system [23]. More broadly, fintech is a line of business that uses diverse software to provide on-demand services related but not limited, to financial services. Often, fintech companies are innovation-oriented startups founded to transform incumbent financial or monetary systems into new, innovative on-demand services.

Based on the functional change of fintech, Arner et al. (2015) differentiated the fintech industry based on three stepwise stages of development over time. In the beginning, fintech 1.0 generation supported better infrastructure for traditional financial services to globalize the financial market from 1866 to 1987. Because of rapid development of digital technology, fintech 2.0 generation focused more on diverse access to the public. That is, fintech, at the time, became a public digital portal for company intranet from 1988 to 2008. From 2008 onward, fintech 3.0 generation shifted its focus from professional company managers to netizens as financial consumers. Based on new demands from financial consumers, fintech 3.0 has actively developed diverse financial services [9]. Lee and Shin (2017) argued that fintech 3.0 or current fintech, consists of a fintech eco-system involving startup companies, traditional financial institutions, financial consumers, fintech developers and governments. According to Korea's Financial Supervisory Service (2018), the fintech business model can be categorized into ten groups: online money transfer and payment, crowdfunding, P2P financing, robot adviser, wealth management, financial security and authentication, financial platform, insurance fintech companies, blockchain and other on-demand services [28]. However, the innovative characteristics of fintech mean that this industry suffers from differentiation because of the legacy regulatory system; thus, a new regulatory approach is necessary [4]. Structurally, all categories of fintech businesses fall under four fintech industries: financial platform, financial data analysis, smart financial services and innovative fintech software [28].

In this study, we examine the new fintech trend-That is, can fintech sustainably maintain competitiveness or efficiency for all firms using it? To become a trend setter, fintech requires appropriate governance with respect to innovation technology and its capacity to change organizational culture. Because governance is a workable mechanism for sustainable performance [29] (p. 3), fintech should harmonize its working networks between technology and organizational culture [30]. Especially, to maintain sustainable fintech development, circular innovation requires both endogenous and exogeneous sources [30]. In this respect, over time, fintech has successfully promoted its competitive edge in new services, new businesses and the resulting profitability for all parties concerned. These aspects are crucial if fintech were to become an innovation platform that transforms the economic structure 
wherein all fintech companies, users and technology developers are proactive actors who enhance the use of fintech for all economic activities. As stated earlier, these activities are not only limited to financial transactions but include a wider range of value-added economic activities. Therefore, many researchers have contended that fintech is based on a circular trend of creative destruction $[5,9,10,12,16,20,21]$.

Creative destruction in our context implies that new fintech services that do not have similarities with traditional marketing characteristics but create new norms, are easily adopted by all industries. Such services abolish the competition criteria through innovation. They are welcomed not only in the traditional low-end market but also in the newly created market. That is, such fintech services lead to better values and more profitable innovations for all markets. A new fintech company can thus easily enter the traditional market and/or create a new market with different conceptual characteristics of its service [31,32]. This creative destruction affects both the traditional financial industry and other industries because fintech products and services can be complementary assets in nationwide economic structures [11]. For example, Alipay in China transformed the Chinese economy into a cashless economy. The resulting innovation led to the establishment of diverse online-to-offline businesses. Similarly, the Alipay revolution popularized the quick response $(\mathrm{QR})$ code to conduct most economic activities. Motivated by the initial success of this payment service, other fintech businesses such as crowdfunding and $\mathrm{P} 2 \mathrm{P}$ businesses are prospering in this region.

In this research, our focus is to examine the role of fintech as a prompter of innovative transformation of the national economy.

\subsection{Literature Review}

The diverse fintech services began after 2010. Although there are different views on when fintech began at first, there is no doubt that the quality of service has elevated after the birth of smartphones after 2010. Thus, various types of studies related to fintech were pointed out after 2010. In this stream of studies related to fintech, the early studies were mostly related to define, categorize and explain the role of fintech [16-19]. Most of the research argued the fintech as a different industry from other industries because of its own unique ecosystem $[5,9,10,12,16,20,21]$. Most of this research focused on the relationship between fintech and financial service industry; not focused on the overall economy of the country.

Over the time, research on the fintech focused on the service users of fintech in micro-perspectives. Kim et al. (2016) argued in their study about the positive influence of the marketing factors such as usefulness, ease of use and credibility and the negative influence of concern for information privacy on user's intention [23]. Chuang et al. (2016) discovered, that such factors of brand and service trust, perceived usefulness, perceived ease of use, made influence on user's attitude and finally the usage intention, based on technology acceptance model (TAM) theory [24]. Moreover, Lim et al. (2019) proved the relationship between variations of confirmation, perceived usefulness and satisfaction that influences the usage of fintech-knowledge and perceived security of the mobile fintech service causes an influence on user confirmation but perceived usefulness, perceived security does not cause an influence on user satisfaction and continual intention to use [26].

Unfortunately, there is very little research to analyze the fintech industry using interindustry analysis; most of the studies were focused on various IT industries and IT convergence industries in macro-perspectives. First, Shin \& Choi (2013) used demand driven model (DDM) and supply driven model (SDM) to analyze the ripple effect of IT service industry of four sections, for five-year period from 1995 to 2009 in South Korea. Over the time, the influence of the IT service that affects the economy of South Korea constantly increased and there were significant differences between each industry affected by different models of IT service [33]. Shin \& Yim (2015) also conducted research related to the development of the IT industry in order to analyze the effect on the Korean IT hardware industry and the IT service industry using DDM and SDM, and on the industry linkage effect. There was a high result that the influence on the Korean economy of the IT hardware industry was bigger compared to the IT service. IT service industry, on the other hand, has lower economic ripple effect than IT hardware 
industry; however, it has higher influence on IT hardware industry compared to other industries [34]. Using this IT related research, we will analyze the effect of the fintech industry on the national economy. Moreover, the studies with interindustry analysis on IT convergence related industry is as follow. Kim et al. (2016) argued smart city which is one of IT convergence related industry and analyzed demand inducement model and industry linkage effect. They discovered that smart city not only allows sustainable city but also takes an important role in nation's economic growth level [35]. Kim et al. (2017) used DDM, SDM and Leontief price Model, as well as the industry linkage effect to analyze the effect of U-healthcare industry that affects Korean economy [34]. The result shows that U-healthcare industry took high effect on production inducement on primary industry and low on price ripple effect [36]. Shin (2018) analyzed mainly job creation part of demand inducement model with interindustry analysis in order to compare the effects on job creation of South Korea and the USA. Shin found out with one million USD of investment for fintech, South Korea can create 20.8 jobs while the USA does only for 15.79 jobs [37].

The diverse studies in the field of fintech and/or IT industries have been actively introduced new phenomena as the fintech ecosystem since after mid-2010s using various subjects and methods. Majority of studies, however, just focused on the innovation of traditional financial industry or fintech user oriented, while most of interindustry analysis studies were related to IT industry and convergence industry. Therefore, this study will contribute to the existing fintech research with the integrative feasibility of the fintech industry as a sustainable innovation platform for not only the financial industry but for the whole national economy.

\section{Methodologies and Empirical Tests}

\subsection{Interindustry Analysis}

The input-output table comprises all nationwide economic activities involving systematically organized transactions among all economic entities and their interrelationships with respect to products and services [37]. This table helps researchers analyze interindustry interrelationships within an economy through a macroeconomic perspective [38]. It systematically explains the output produced by one industry as the input for another industry within the complete industry ecosystem. Indeed, examining the unexpected change in one input or exogeneous shocks (e.g., an innovative technology) over all industries is meaningful. Based on this general equilibrium type of national economy, we can examine or predict the effect of an external policy shock or a new technology innovation. Because an interindustry analysis reveals both direct and indirect effects of external shocks on the national economy, it is useful for examining the feasibility of fintech as a platform that leads to industry-wide diverse spillover effects. A substantial amount of studies on the IT industry are based on such an interindustry analysis $[33,34,39,40]$.

Research on the fintech industry is conventionally an interdisciplinary analysis that includes both the IT and financial industries. Therefore, we use an interindustry analysis based on the 2015 input-output table published by Bank of Korea [41]. We use this input-output table to systematically examine the feasibility of the fintech industry by innovation platform for sustainable economic growth. In the first stage, we use the production inducing effect and value-added inducing effect on the DDM, supply shortage effect on the SDM and industry linkage effect for the fintech subindustry sectors. In addition, we use the exogenous specification approach in the initiation of the model [42]. Through this exogenous specification, we can effectively separate the direct and indirect effects of the fintech industry. Here, the direct effects refer to the economic effect of the fintech industry itself and the indirect effects refer to the influence on other industries except for the impact of the fintech industry itself.

In order to achieve the purpose of this study, we shall quantitatively identify the extent of the production-inducing, value-added inducing effects of the fintech industry and the financial industry. It can also explore the economic role of the fintech and financial industries. These results can be 
used to assess whether the fintech industry can serve as an economic innovation platform for all industries nationwide.

\subsection{Demand-Driven Model (DDM)}

To examine the production inducement effect, we evaluate the input coefficients $\left(\alpha_{i j}\right)$ using the intermediate goods $\left(X_{i j}\right)$ of the specific fintech industry divided its total outputs $\left(X_{i}\right)$. Placing all these input coefficients along the input-output table allows us to obtain the production input coefficient table (A). We evaluate these coefficients as follows:

$$
i j \text { Interindustry input coefficient, } \alpha_{i j}=\frac{X_{i j}}{X_{j}}
$$

where $X_{i}$ is the input amount in subsector $i$ and $X_{i j}$ is the input amount in subsector $j$ by intermediate inputs $x_{i}$.

We can evaluate the production inducement coefficients through the exogenous variables of the table above:

$$
\text { Production inducement coefficient, } \alpha_{i j}=(I-A)^{-1} A_{s}
$$

where $A_{S}$ is the reorganized input coefficient line vector in each subsector, $I$ is the diagonal matrix with diagonal vector 1 and $A$ is the production input coefficient table with each coefficient $\left(\alpha_{i j}\right)$.

We can evaluate the value-added coefficients on the input-output table using each industry's added value amount for all industries' total output:

$$
\text { Value added coefficient of the subsector, } j, v_{j}=\frac{V_{j}}{X_{j}}
$$

where $V_{j}$ is the added value amount of subsector $j$.

The value-added inducement coefficient is the new value of the national economy yielded from all the subjects in the research. We can evaluate it by integrating all the production inducing effects of the subjects:

$$
\text { Value added inducement coefficient }=\check{\vartheta}_{i}(I-A)^{-1} A_{s}
$$

where $\check{v_{i}}$ is diagonal vector of the value-added coefficient and $(I-A)^{-1} A_{s}$ is the production inducement coefficient.

\subsection{Supply-driven Model (SDM)}

To evaluate the supply shortage effect on the SIM, we must first calculate the output coefficient table- that is, the output coefficient $\left(R_{i j}\right)$ is the total amount of intermediate goods divided the total produced amount to produce any specific goods or services. Replacing all these coefficients on the input-output table yields the output coefficient table. We evaluate each output coefficient as follows:

$$
\text { Output coefficient of the interindustry of } i j, R_{i j}=\frac{X_{i j}}{X_{i}}
$$

where $X_{i}$ is the output of subsector $i$ and $X_{i j}$ is the output amount in subsector $i$ by intermediate inputs $j$.

Next, we evaluate the supply shortage coefficients when the target subsector becomes exogenous to the output coefficient table above:

$$
\text { Supply shortage coefficient }=R_{S}(I-R)^{-1}
$$

where $R_{s}$ is the output coefficient horizontal vector of the subsector, $I$ is 1 diagonal matrix with diagonal vector 1 and $R$ is the output coefficient matrix $\left(\alpha_{i j}\right)$ 


\subsection{Industry Linkage Effect}

The industry linkage effect consists of forward and background linkage effects. The forward linkage effect $\left(F L_{i}\right)$ comprises the sensitivity coefficients, which indicates the amount by subsector $i$ should increase its product or service output to increase one unit of the final demand. Equation (7) shows this coefficient, which arises from the horizontal sum of the production inducement coefficients divided by the average sum of the production inducement coefficients of all industries.

$$
F L_{i}=\frac{\frac{1}{n} \sum_{j=1}^{n} \alpha_{i j}}{\frac{1}{n^{2}} \sum_{i=1}^{n} \sum_{j=1}^{n} \alpha_{i j}}
$$

The background linkage effect $\left(B L_{i}\right)$ or influential coefficient implies that the ripple effect of the subsector produces its own production for all other industries that produce their output as inputs of this subsector. We can evaluate this effect using the subsector's production inducement coefficients divided by the average production inducement coefficients $\left(\alpha_{i j}\right)$ of all industries, as shown in Equation (8).

$$
B L_{i}=\frac{\frac{1}{n} \sum_{i=1}^{n} \alpha_{i j}}{\frac{1}{n^{2}} \sum_{i=1}^{n} \sum_{j=1}^{n} \alpha_{i j}}
$$

\subsection{Research Process}

Figure 1 shows the research structure and each stage in the stepwise process. Our primary focus is a comparative analysis of the functional role of the national economy with respect to the fintech and traditional or ordinary, financial industries, especially the fintech banking and insurance subsectors.

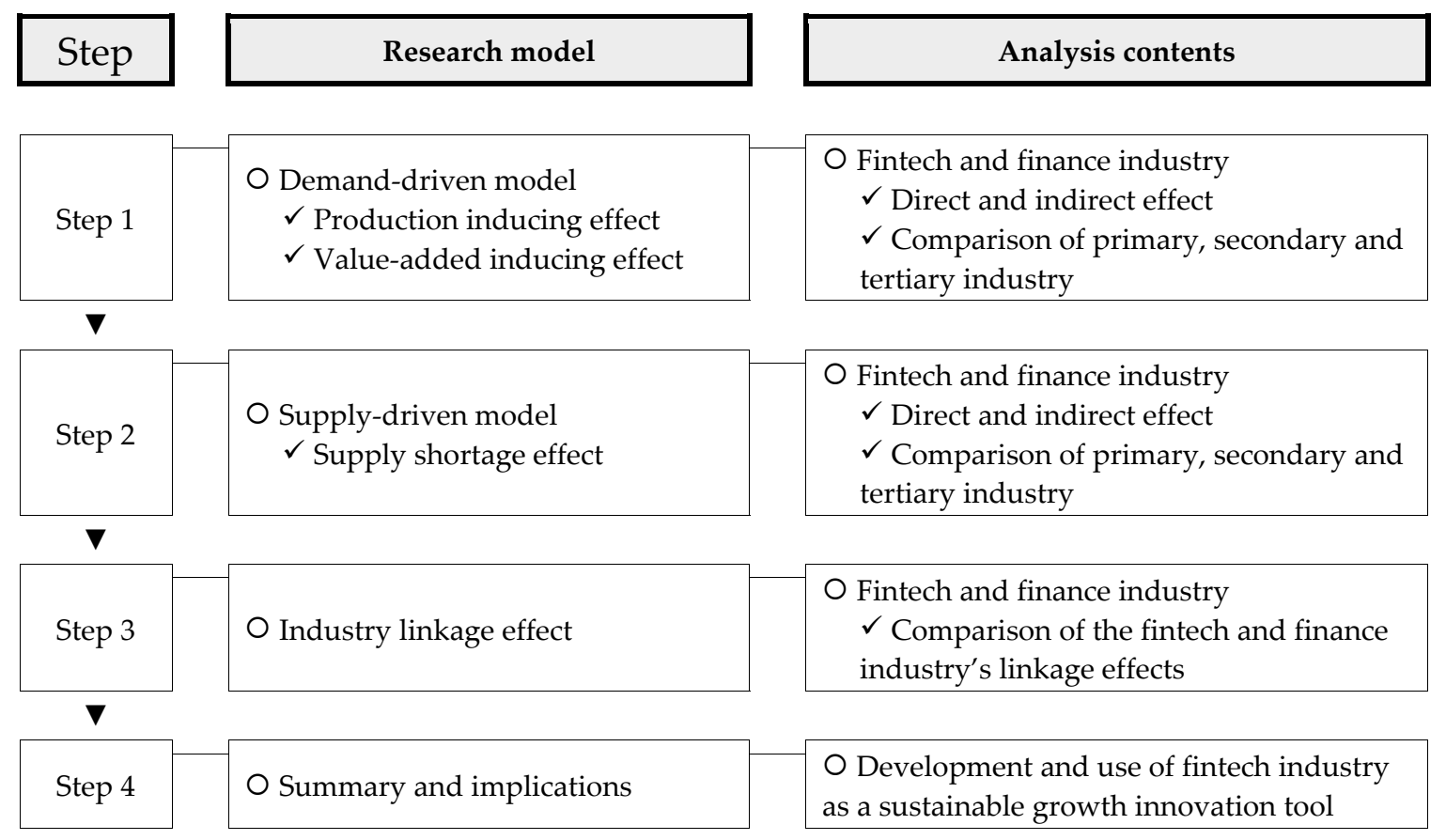

Figure 1. Research process.

In the first stage, we use the DDM to evaluate the production and value-added inducing effects. We use the results obtained to compare the fintech industry with the ordinary financial industry through the direct and indirect effects in the primary, secondary and tertiary industries. This, in turn, allows us to evaluate the feasibility of fintech as a sustainable platform for the national economy. 
In the second stage, we use the SDM to evaluate and compare the supply shortage effects of the fintech and ordinary financial industries.

In the third stage, we finally evaluate the forward and background linkage effects of the fintech and ordinary financial industries.

We interpret all the comparative results and present some implications and suggestions. In the next section, we explain new global and Korean trends in the fintech industry as well as its future.

\section{Fintech Industry: Status and Classification}

\subsection{Current Status of Fintech Industry}

In Korea, the fintech industry illustrates one of the core challenges of the future economy as per the government. However, the success of fintech in Korea is marked with difficulty. It Korea, the basic paradigm of the economic policies is based on a positive system. That is, all new businesses or services may be established only when there exist previous samples and/or with permitted regulation. The old legacy regulation system cannot allow fintech entrants into the market because of the latter's novel services. Thus, there are serious invisible barriers for fintech startups in Korea. Even if the government creates a special deregulatory zone for fintech startups within a so-called regulatory sand box, most fintech startups would still be encumbered by excessive regulations on their new services and businesses [28]. For example, all online financial transactions were first based on public authentication under unified regulation. However, new fintech services with diverse IT infrastructure could not optimally perform in this system, leading the Korean government to eliminate the public unified authentication, though it was difficult for financial consumers and institutions to change their new platform. Similarly, there is excess regulation on new fintech services in Korea vis-à-vis the basic "positive system."

Nonetheless, the fintech industry has been rapidly growing through the transformation of traditional financial institutions such as banks and insurance companies into enhanced smart financial services supported by fintech. In 2017, smart payments and online transfer services together accounted for $2.806 \mathrm{mn}$ transactions amounting to $102.307 \mathrm{mn}$ (US\$ $95 \mathrm{bn}$ ) (Table 1). The growth rates of these services were 180.1 percent and 212 percent, respectively, compared with the previous year [28]. Most other fintech businesses showed similar growth rates as in Table 1.

Table 1. Use Status of Simple Payment Service (Based on Daily Average) (Unit: 1000 cases; in millions).

\begin{tabular}{cccccccc}
\hline & $\mathbf{2 0 1 6}(\mathbf{A})$ & $\mathbf{2 0 1 7}(\mathbf{B})$ & $\mathbf{1 / 4}$ & $\mathbf{2 / 4}$ & $\mathbf{3 / 4}$ & $\mathbf{4 / 4}$ & (B-A) \\
\hline \multirow{2}{*}{ Number of uses } & 1002.2 & 2806.8 & 1644.6 & 2458.3 & 3398.7 & 3696.6 & 1804.6 \\
& $(-)$ & $(180.1)$ & $(9.2)$ & $(49.5)$ & $(38.3)$ & $(8.8)$ & \\
Amount used & $32,793.6$ & $102,306.6$ & $62,261.2$ & $84,215.6$ & $115,578.0$ & $146,104.2$ & $69,513.0$ \\
& $(-)$ & $(212.0)$ & $(19.0)$ & $(35.3)$ & $(37.2)$ & $(26.4)$ & \\
\hline
\end{tabular}

Note: The values in parentheses indicate increasing and decreasing rates compared with the previous quarter in percentage. Source: Korea Financial Supervisory Service (2018) [28].

As reported in Table 2, some startups in the new fintech services outperformed. Of the traditional financial institutions, new intermediaries for P2P loan and lending services showed a dramatic increase from $\$ 628.9$ bn (US\$ 5.24 bn) in 2016 to 2967.4 bn (US\$ 24.72 bn) in 2018, attributed to the 194 companies in this category of fintech companies [28]. 
Table 2. P2P Cumulative Loans and Loan Balance Scale (Unit: $100 \mathrm{mn}$; \%).

\begin{tabular}{ccccccc}
\hline & 16 End & 17.3 End & 17.6 End & 17.9 End & 17 End & 18.3 End \\
\hline Accumulated loan amount & 6289 & 9628 & 13,981 & 18,461 & 23,400 & 29,674 \\
QoQ increase & - & +3339 & +4353 & +4480 & +4939 & +6274 \\
QoQ growth rate & - & 53.1 & 45.2 & 32.0 & 26.8 & 26.8 \\
Loan balance & 4140 & 4360 & 6108 & 7300 & 8296 & 10,013 \\
QoQ increase & - & +220 & +1748 & +1192 & +996 & +1717 \\
QoQ growth rate & - & 5.3 & 40.1 & 19.5 & 13.6 & 20.7 \\
\hline
\end{tabular}

Note: 65 companies based on Korea P2P Financial Association. Source: Korea Financial Supervisory Service (2018) [28].

\subsection{New Classification of the Fintech Industry}

To examine the ripple effect of the fintech industry on all industries nationwide, we analyze the production inducing effect and value-added inducing effect using the DDM, supply shortage effect from the SIM and industry linkage effect including forward and background linkage effects. To examine the fintech industry in more detail, we more broadly reorganize or reclassify the fintech industry according to the industrial classification of the Korean Financial Services Commission (FSC).

Based on the Korean standard industrial classification, the FSC classified fintech industry into four categories: electronic financial provider, electronic financial assistant, financial computing industry (Bank) and new trend (Table 3). Among these subsectors, the new trend subsector consists of three IT-related fields: financial data analysis, financial software and financial platform. These business are extremely new and highly differentiated from the traditional financial industry, which consists of nine subsectors (e.g., S/W development and supply business; see Table 4). Because the electronic financial assistant subsector (e.g., information system operators and service companies) falls under the IT industry class, we could further classify the fintech industry into IT, finance and a new trend for financial support.

Table 3. Classification of Fintech Companies in Korea's Standard Industry Classification.

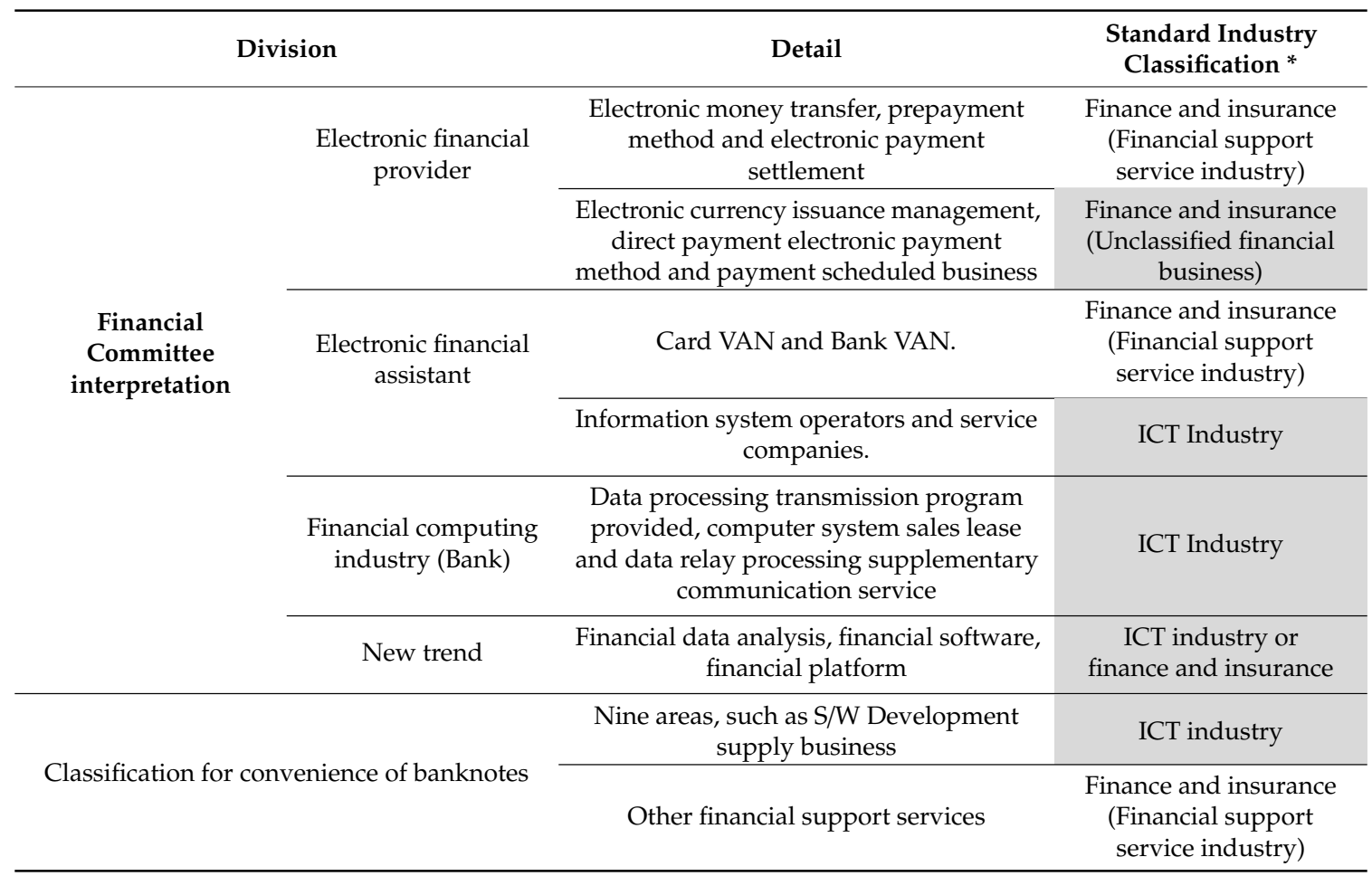

Note: * The shaded areas are classified by the authors because they are unclear in the standard industry classification by the Korean government. Source: Financial Services Commission Press Release (November 27, 2018) [43]. 
Table 4. Fintech Industry Classification Based on Input-output tables.

\begin{tabular}{|c|c|c|c|c|c|c|c|c|}
\hline Classification & No & Industry Sector & Fintech & $\begin{array}{l}\text { FinTech } \\
\text { Banking }\end{array}$ & Insuretech & Finance & Bank & Insurance \\
\hline \multirow{9}{*}{ ICT hardware } & 079 & Electricity conversion. Supply control device & $\mathrm{O}$ & $\mathrm{O}$ & $\mathrm{O}$ & & \multirow{14}{*}{ Not applicable } & \\
\hline & 080 & Battery & $\mathrm{O}$ & $\mathrm{O}$ & $\mathrm{O}$ & & & \\
\hline & 081 & Other electrical equipment & $\mathrm{O}$ & $\mathrm{O}$ & $\mathrm{O}$ & & & \\
\hline & 082 & Semiconductor & $\mathrm{O}$ & $\mathrm{O}$ & $\mathrm{O}$ & & & \\
\hline & 083 & Electronic display device & $\mathrm{O}$ & $\mathrm{O}$ & $\mathrm{O}$ & & & \\
\hline & 084 & Printed circuit board & $\mathrm{O}$ & $\mathrm{O}$ & $\mathrm{O}$ & & & \\
\hline & 085 & Other Electronic Components & $\mathrm{O}$ & $\mathrm{O}$ & $\mathrm{O}$ & & & \\
\hline & 086 & Computers and Peripherals & $\mathrm{O}$ & $\mathrm{O}$ & $\mathrm{O}$ & & & \\
\hline & 087 & Communication and broadcasting equipment & $\mathrm{O}$ & $\mathrm{O}$ & $\mathrm{O}$ & & & \\
\hline \multirow{3}{*}{$\begin{array}{l}\text { Communication } \\
\text { services }\end{array}$} & 128 & Wired and wireless communication service & $\mathrm{O}$ & $\mathrm{O}$ & $\mathrm{O}$ & & & \\
\hline & 129 & Other Telecommunications Services & $\mathrm{O}$ & $\mathrm{O}$ & $\mathrm{O}$ & & & \\
\hline & 131 & Information service & $\mathrm{O}$ & $\mathrm{O}$ & $\mathrm{O}$ & & & \\
\hline \multirow[b]{2}{*}{ IT services } & 132 & Supply of software development & $\mathrm{O}$ & $\mathrm{O}$ & $\mathrm{O}$ & & & \\
\hline & 133 & Computer Management Services & $\mathrm{O}$ & $\mathrm{O}$ & $\mathrm{O}$ & & & \\
\hline \multirow{3}{*}{ Finance } & 137 & Banking services & $\mathrm{O}$ & $\mathrm{O}$ & Not applicable & $\mathrm{O}$ & $\mathrm{O}$ & Not applicable \\
\hline & 138 & Insurance Services & $\mathrm{O}$ & Not applicable & $\mathrm{O}$ & $\mathrm{O}$ & Not applicable & $\mathrm{O}$ \\
\hline & 139 & Financial and Insurance Assistance Services & $\mathrm{O}$ & $\mathrm{O}$ & $\mathrm{O}$ & $\mathrm{O}$ & $\mathrm{O}$ & $\mathrm{O}$ \\
\hline
\end{tabular}


Shin (2018) simplified this classification into IT and finance only [4]. Based on this basic classification and the arguments presented above, we classify the fintech industry into four categories-information and communication technology (ICT) hardware, ICT services, software development and financial services (Table 4) [37].

To evaluate all the direct and indirect ripple effect of the fintech industry, we use the exogenous approach to the national economy represented by the input-output table. Table 5 reports the rearranged industry classification based on Table 5. Note that the last class, 33, includes all the fintech subsectors mentioned in Table 5; these include fintech banking, fintech insurance and (traditional) finance of banking and insurance. That is, we modified the 32 classifications of the original industries by introducing a new category for the fintech industry. Because some industries, such as class 24 , consist of traditional finance sectors that already exist in class 33 , we leave a blank for class 24 . Similarly, there are several subsectors with overlapping input and output, which we leave as blanks in Table 5 .

Table 5. Industry Classification for the Analysis of Input-Output Analysis.

\begin{tabular}{|c|c|c|c|c|c|c|c|c|}
\hline No. & Code & Sector & No. & Code & Sector & No. & Code & Sector \\
\hline 1 & A & $\begin{array}{l}\text { Agriculture, forestry } \\
\text { and fisheries products }\end{array}$ & 12 & $\mathrm{C} 10$ & Electrical equipment & 23 & $\mathrm{~J}$ & $\begin{array}{l}\text { Information and } \\
\text { communication/broadcasting } \\
\text { and newspaper and } \\
\text { publishing }\end{array}$ \\
\hline 2 & B & Minerals & 13 & $\mathrm{C} 11$ & $\begin{array}{l}\text { Machinery and } \\
\text { equipment }\end{array}$ & 24 & K & ()/insurance/banking/() \\
\hline 3 & $\mathrm{C} 01$ & Food and beverage & 14 & $\mathrm{C} 12$ & $\begin{array}{c}\text { Transportation } \\
\text { equipment }\end{array}$ & 25 & $\mathrm{~L}$ & Real estate services \\
\hline 4 & $\mathrm{C} 02$ & $\begin{array}{l}\text { Textiles and leather } \\
\text { products }\end{array}$ & 15 & $\mathrm{C} 13$ & $\begin{array}{l}\text { Other } \\
\text { manufacturing } \\
\text { products }\end{array}$ & 26 & M & $\begin{array}{l}\text { Professional, scientific and } \\
\text { technical services }\end{array}$ \\
\hline 5 & $\mathrm{C} 03$ & $\begin{array}{l}\text { Wood and paper and } \\
\text { printing }\end{array}$ & 16 & $\mathrm{C} 14$ & $\begin{array}{l}\text { Manufacturing and } \\
\text { industrial } \\
\text { equipment repairs }\end{array}$ & 27 & $\mathrm{~N}$ & Business services \\
\hline 6 & $\mathrm{C} 04$ & $\begin{array}{l}\text { Coal and petroleum } \\
\text { products }\end{array}$ & 17 & $\mathrm{D}$ & $\begin{array}{l}\text { Electricity, gas and } \\
\text { steam }\end{array}$ & 28 & $\mathrm{O}$ & $\begin{array}{c}\text { Public administration, } \\
\text { defense and social security }\end{array}$ \\
\hline 7 & $\mathrm{C} 05$ & Chemicals & 18 & $\mathrm{E}$ & $\begin{array}{l}\text { Water, waste } \\
\text { disposal and } \\
\text { recycling services }\end{array}$ & 29 & $\mathrm{P}$ & Education services \\
\hline 8 & $\mathrm{C} 06$ & $\begin{array}{l}\text { Nonmetallic mineral } \\
\text { products }\end{array}$ & 19 & $\mathrm{~F}$ & Construction & 30 & Q & Health and social services \\
\hline 9 & $\mathrm{C} 07$ & Primary metal products & 20 & G & $\begin{array}{l}\text { Wholesale and retail } \\
\text { trade services }\end{array}$ & 31 & $\mathrm{R}$ & $\begin{array}{l}\text { Arts, sports and leisure } \\
\text { services }\end{array}$ \\
\hline 10 & $\mathrm{C} 08$ & $\begin{array}{l}\text { Fabricated metal } \\
\text { products }\end{array}$ & 21 & $\mathrm{H}$ & $\begin{array}{l}\text { Transportation } \\
\text { services }\end{array}$ & 32 & $\mathrm{~S}$ & Other services \\
\hline 11 & $\mathrm{C} 09$ & $\begin{array}{l}\text { Computers, electronics/ } \\
\text { precision instruments }\end{array}$ & 22 & I & $\begin{array}{l}\text { Accommodation } \\
\text { and food services }\end{array}$ & 33 & Goal & $\begin{array}{c}\text { Fintech/fintech } \\
\text { banking/insuretech } \\
\text { finance/bank/insurance }\end{array}$ \\
\hline
\end{tabular}

\section{Empirical Evaluation and Results}

\subsection{Ripple Effects on the Demand-driven Model}

As shown in Figure 1, we evaluate the production and value-added inducing effects based on the DDM in the first stage. Here, the production inducing effect implies the degree to which other industries must increase or induce production for the subject subsector to produce one unit of product. We find in Table 6 that, with a unit increase of production, fintech induced a value of 2.006 for all other industries. In the fintech industry, the fintech banking subsector induced 2.011 and insurance induced 2.071. On the other hand, the financial industry induced 1.674 overall, whereas its banking subsector induced 1.564 and insurance induced 1.836 . This comparison shows that the fintech industry has a stronger production inducing effect. In the sub-sectoral comparison, the insurance subsector dominates the banking subsector. It is possible that the wide application of fintech data results in this industry's higher performance in the production inducing effect. 
Table 6. Results of the Production Inducing Effects.

\begin{tabular}{|c|c|c|c|c|c|c|c|c|c|c|c|c|c|}
\hline \multirow{2}{*}{ Code } & \multirow{2}{*}{ Production Inducing Effects } & \multicolumn{2}{|c|}{ Fintech } & \multicolumn{2}{|c|}{ Fintech Banking } & \multicolumn{2}{|c|}{ Insuretech } & \multicolumn{2}{|c|}{ Finance } & \multicolumn{2}{|c|}{ Bank } & \multicolumn{2}{|c|}{ Insurance } \\
\hline & & Effects & Rank & Effects & Rank & Effects & Rank & Effects & Rank & Effects & Rank & Effects & Rank \\
\hline A & Agriculture, forestry and fisheries products & 0.009 & 21 & 0.009 & 20 & 0.009 & 22 & 0.008 & 17 & 0.007 & 16 & 0.009 & 18 \\
\hline B & Minerals & 0.031 & 6 & 0.033 & 6 & 0.034 & 6 & 0.013 & 12 & 0.012 & 12 & 0.015 & 13 \\
\hline $\mathrm{C} 01$ & Food and beverage & 0.025 & 10 & 0.025 & 9 & 0.026 & 9 & 0.024 & 6 & 0.022 & 7 & 0.028 & 7 \\
\hline $\mathrm{C} 02$ & Textiles and leather products & 0.013 & 16 & 0.013 & 17 & 0.013 & 18 & 0.010 & 14 & 0.009 & 14 & 0.012 & 15 \\
\hline $\mathrm{C} 03$ & Wood and paper and printing & 0.007 & 23 & 0.007 & 23 & 0.007 & 24 & 0.011 & 13 & 0.011 & 13 & 0.010 & 16 \\
\hline $\mathrm{C} 04$ & Coal and petroleum products & 0.021 & 13 & 0.022 & 13 & 0.023 & 14 & 0.009 & 15 & 0.009 & 15 & 0.010 & 17 \\
\hline $\mathrm{C} 05$ & Chemicals & 0.082 & 1 & 0.086 & 1 & 0.091 & 1 & 0.022 & 8 & 0.020 & 8 & 0.026 & 9 \\
\hline $\mathrm{C} 06$ & Nonmetallic mineral products & 0.012 & 17 & 0.013 & 16 & 0.014 & 17 & 0.002 & 30 & 0.002 & 30 & 0.002 & 31 \\
\hline $\mathrm{C} 07$ & Primary metal products & 0.027 & 7 & 0.028 & 7 & 0.030 & 7 & 0.006 & 20 & 0.006 & 20 & 0.007 & 21 \\
\hline $\mathrm{C} 08$ & Fabricated metal products & 0.014 & 15 & 0.015 & 15 & 0.015 & 16 & 0.006 & 21 & 0.006 & 21 & 0.006 & 22 \\
\hline $\mathrm{C} 09$ & Computers and electronics/precision instruments & 0.009 & 19 & 0.010 & 19 & 0.010 & 20 & 0.018 & 10 & 0.018 & 10 & 0.019 & 12 \\
\hline $\mathrm{C} 10$ & Electrical equipment & 0.023 & 11 & 0.024 & 10 & 0.026 & 10 & 0.007 & 19 & 0.007 & 17 & 0.008 & 20 \\
\hline C11 & Machinery and equipment & 0.011 & 18 & 0.012 & 18 & 0.013 & 19 & 0.004 & 27 & 0.003 & 27 & 0.004 & 28 \\
\hline $\mathrm{C} 12$ & Transportation equipment & 0.007 & 22 & 0.008 & 22 & 0.008 & 23 & 0.004 & 24 & 0.004 & 23 & 0.005 & 25 \\
\hline $\mathrm{C} 13$ & Other manufacturing products & 0.004 & 26 & 0.004 & 27 & 0.004 & 27 & 0.004 & 23 & 0.003 & 26 & 0.005 & 24 \\
\hline C14 & Manufacturing and industrial equipment repairs & 0.023 & 12 & 0.024 & 11 & 0.025 & 11 & 0.007 & 18 & 0.007 & 18 & 0.008 & 19 \\
\hline $\mathrm{D}$ & Electricity, gas and steam & 0.034 & 5 & 0.035 & 5 & 0.037 & 5 & 0.017 & 11 & 0.015 & 11 & 0.021 & 10 \\
\hline E & Water, waste disposal and recycling services & 0.004 & 24 & 0.004 & 25 & 0.005 & 25 & 0.004 & 26 & 0.003 & 28 & 0.004 & 27 \\
\hline $\mathrm{F}$ & Construction & 0.003 & 28 & 0.003 & 29 & 0.003 & 29 & 0.003 & 28 & 0.003 & 29 & 0.004 & 29 \\
\hline G & Wholesale and retail trade services & 0.049 & 2 & 0.051 & 2 & 0.054 & 2 & 0.024 & 7 & 0.022 & 6 & 0.027 & 8 \\
\hline $\mathrm{H}$ & Transportation services & 0.039 & 4 & 0.041 & 3 & 0.043 & 3 & 0.020 & 9 & 0.020 & 9 & 0.021 & 11 \\
\hline $\mathrm{I}$ & Accommodation and food services & 0.026 & 8 & 0.026 & 8 & 0.027 & 8 & 0.031 & 5 & 0.028 & 5 & 0.034 & 6 \\
\hline $\mathrm{J}$ & $\begin{array}{c}\text { Information and communication/broadcasting and newspaper } \\
\text { and publishing }\end{array}$ & 0.016 & 14 & 0.017 & 14 & 0.018 & 15 & 0.073 & 1 & 0.078 & 1 & 0.067 & 2 \\
\hline $\mathrm{K}$ & ()/insurance/banking/() & & & 0.005 & 24 & 0.025 & 12 & & & 0.004 & 22 & 0.054 & 4 \\
\hline $\mathrm{L}$ & Real estate services & 0.025 & 9 & 0.023 & 12 & 0.025 & 13 & 0.045 & 4 & 0.040 & 4 & 0.058 & 3 \\
\hline $\mathrm{M}$ & Professional, scientific and technical services & 0.041 & 3 & 0.039 & 4 & 0.040 & 4 & 0.048 & 3 & 0.045 & 3 & 0.054 & 5 \\
\hline $\mathrm{N}$ & Business services & & & & & & & 0.061 & 2 & 0.054 & 2 & 0.070 & 1 \\
\hline $\mathrm{O}$ & Public administration, defense and social security & 0.000 & 30 & 0.000 & 31 & 0.001 & 31 & 0.000 & 31 & 0.000 & 32 & 0.001 & 32 \\
\hline $\mathrm{P}$ & Education services & 0.001 & 29 & 0.001 & 30 & 0.001 & 30 & 0.002 & 29 & 0.002 & 31 & 0.003 & 30 \\
\hline $\mathrm{Q}$ & Health and social services & 0.003 & 27 & 0.003 & 28 & 0.003 & 28 & 0.005 & 22 & 0.004 & 24 & 0.006 & 23 \\
\hline $\mathrm{R}$ & Arts, sports and leisure services & 0.004 & 25 & 0.004 & 26 & 0.004 & 26 & 0.004 & 25 & 0.004 & 25 & 0.005 & 26 \\
\hline $\mathrm{S}$ & Other services & 0.009 & 20 & 0.008 & 21 & 0.009 & 21 & 0.009 & 16 & 0.006 & 19 & 0.012 & 14 \\
\hline & Indirect effect & 0.573 & $28.6 \%$ & 0.594 & $29.5 \%$ & 0.643 & $31.0 \%$ & 0.501 & $29.9 \%$ & 0.473 & $30.2 \%$ & 0.614 & $33.4 \%$ \\
\hline & Direct effect & 1.433 & $71.4 \%$ & 1.417 & $70.5 \%$ & 1.428 & $69.0 \%$ & 1.173 & $70.1 \%$ & 1.091 & $69.8 \%$ & 1.222 & $66.6 \%$ \\
\hline & Total effect & 2.006 & $100.0 \%$ & 2.011 & $100.0 \%$ & 2.071 & $100.0 \%$ & 1.674 & $100.0 \%$ & 1.564 & $100.0 \%$ & 1.836 & $100.0 \%$ \\
\hline
\end{tabular}


With respect to the other industries, the fintech industry has a stronger production inducing effect on $\mathrm{C} 05$ chemicals, whereas the financial industry has a stronger production inducing effect on the J group of "Information and communication/broadcasting and newspaper and publishing." This comparative result also supports the conclusion above- that is, wider application of ICT may result in higher performance in the production inducing effect.

As shown in Figure 2, the fintech industry has a stronger production inducing effect for both the direct and indirect effects compared with the financial industry. Especially, the indirect effect with respect to the other industry of fintech is 69 percent to 71.4 percent-higher than the financial industry. That is, fintech can better promote all other industries' production inducement as a prompter that enhances the competitiveness of the national economy.

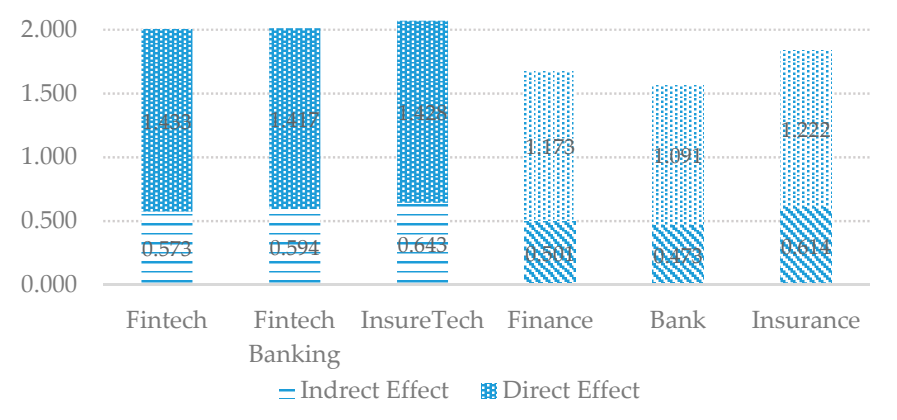

Figure 2. Production Inducing Effects.

Table 7 reports the indirect production inducing effect for all the other industries nationwide. Overall, the fintech industry affects the secondary manufacturing industry at a 55.8 percent rate and affects the tertiary service industry at a 37.3 percent rate, which is much higher than the financial industry. Fintech has stronger effects on the secondary industry, whereas this holds true for the financial and tertiary industries. That is, the fintech industry has strong feasibility as a platform to induce other manufacturing industries' production.

Table 7. Rate of Production Inducing Effects.

\begin{tabular}{ccccccccccccc}
\hline & \multicolumn{2}{c}{ Fintech } & \multicolumn{2}{c}{ Fintech Banking } & \multicolumn{2}{c}{ Insuretech } & \multicolumn{2}{c}{ Finance } & \multicolumn{2}{c}{ Bank } & \multicolumn{2}{c}{ Insurance } \\
\hline Primary industry & 0.040 & $7.0 \%$ & 0.041 & $7.0 \%$ & 0.043 & $6.8 \%$ & 0.021 & $4.3 \%$ & 0.019 & $4.1 \%$ & 0.025 & $4.0 \%$ \\
Secondary industry & 0.320 & $55.8 \%$ & 0.334 & $56.2 \%$ & 0.350 & $54.5 \%$ & 0.159 & $31.7 \%$ & 0.146 & $30.8 \%$ & 0.180 & $29.3 \%$ \\
Tertiary industry & 0.214 & $37.3 \%$ & 0.219 & $36.9 \%$ & 0.249 & $38.7 \%$ & 0.321 & $64.0 \%$ & 0.308 & $65.1 \%$ & 0.410 & $66.7 \%$ \\
\hline
\end{tabular}

To examine the feasibility of fintech as a platform of the national economy, we evaluate the value-added inducing effect (Table 8). The value-added inducing effect implies the degree to which other industries should increase or induce value-added activities for the subject subsector to produce one more unit of added value.

Table 8 reports that, with a unit increase of added value, fintech induced 0.689 for all other industries. In the fintech industry, the fintech banking subsector induced 0.702 and fintech insurance induced 0.692 . However, the financial industry induced 0.806 value overall, whereas its banking subsector induced 0.889 and insurance subsector induced 0.743 . Thus, the fintech industry has a marginally lower value-added inducing effect. It is more manufacture-oriented as a platform of the national economy, whereas the financial industry is purely service-oriented, with higher value-added inducing effects on other industries.

With respect to the other industries, the fintech industry has a stronger value-added inducing effect on "professional, scientific and technical services" (M) as well as "nonmetallic mineral products" (C06), whereas the financial industry has a stronger production inducing effect on "information and communication/broadcasting, newspaper and publishing" (J) and "real estate services" (L). Compared with the production inducing effect, the value-added inducing effect on the subsector of "banking and insurance" is almost similar between fintech and financial industries. 
Table 8. Results of Value-Added Inducing Effects.

\begin{tabular}{|c|c|c|c|c|c|c|c|c|c|c|c|c|c|}
\hline \multirow{2}{*}{ Code } & \multirow{2}{*}{ Value Added Inducing Effects } & \multicolumn{2}{|c|}{ Fintech } & \multicolumn{2}{|c|}{ Fintech Banking } & \multicolumn{2}{|c|}{ InsureTech } & \multicolumn{2}{|c|}{ Finance } & \multicolumn{2}{|c|}{ Bank } & \multicolumn{2}{|c|}{ Insurance } \\
\hline & & Effects & Rank & Effects & Rank & Effects & Rank & Effects & Rank & Effects & Rank & Effects & Rank \\
\hline A & Agriculture, forestry and fisheries products & 0.005 & 14 & 0.005 & 14 & 0.005 & 15 & 0.004 & 12 & 0.004 & 12 & 0.005 & 13 \\
\hline B & Minerals & 0.017 & 5 & 0.017 & 4 & 0.018 & 5 & 0.007 & 8 & 0.006 & 8 & 0.008 & 9 \\
\hline $\mathrm{C} 01$ & Food and beverage & 0.004 & 15 & 0.004 & 15 & 0.005 & 16 & 0.004 & 13 & 0.004 & 13 & 0.005 & 14 \\
\hline $\mathrm{C} 02$ & Textiles and leather products & 0.004 & 17 & 0.004 & 17 & 0.004 & 18 & 0.003 & 17 & 0.003 & 16 & 0.003 & 18 \\
\hline $\mathrm{C} 03$ & Wood and paper and printing & 0.003 & 22 & 0.003 & 22 & 0.003 & 23 & 0.004 & 14 & 0.004 & 14 & 0.004 & 17 \\
\hline $\mathrm{C} 04$ & Coal and petroleum products & 0.003 & 20 & 0.003 & 20 & 0.003 & 21 & 0.001 & 24 & 0.001 & 24 & 0.001 & 25 \\
\hline $\mathrm{C} 05$ & Chemicals & 0.023 & 3 & 0.024 & 3 & 0.026 & 3 & 0.006 & 9 & 0.006 & 10 & 0.007 & 11 \\
\hline $\mathrm{C} 06$ & Nonmetallic mineral products & 0.004 & 16 & 0.004 & 16 & 0.004 & 17 & 0.001 & 30 & 0.001 & 31 & 0.001 & 31 \\
\hline $\mathrm{C} 07$ & Primary metal products & 0.005 & 12 & 0.006 & 12 & 0.006 & 13 & 0.001 & 25 & 0.001 & 26 & 0.001 & 27 \\
\hline $\mathrm{C} 08$ & Fabricated metal products & 0.005 & 13 & 0.005 & 13 & 0.005 & 14 & 0.002 & 20 & 0.002 & 19 & 0.002 & 23 \\
\hline C09 & Computers and electronics/precision instruments & 0.003 & 21 & 0.003 & 21 & 0.003 & 22 & 0.006 & 11 & 0.006 & 9 & 0.006 & 12 \\
\hline $\mathrm{C} 10$ & Electrical equipment & 0.007 & 10 & 0.007 & 10 & 0.008 & 11 & 0.002 & 19 & 0.002 & 18 & 0.002 & 20 \\
\hline C11 & Machinery and equipment & 0.003 & 19 & 0.004 & 18 & 0.004 & 19 & 0.001 & 28 & 0.001 & 28 & 0.001 & 29 \\
\hline $\mathrm{C} 12$ & Transportation equipment & 0.001 & 26 & 0.001 & 27 & 0.001 & 27 & 0.001 & 29 & 0.001 & 30 & 0.001 & 30 \\
\hline $\mathrm{C} 13$ & Other manufacturing products & 0.001 & 28 & 0.001 & 29 & 0.001 & 29 & 0.001 & 27 & 0.001 & 29 & 0.001 & 26 \\
\hline C14 & Manufacturing and industrial equipment repairs & 0.011 & 8 & 0.012 & 8 & 0.012 & 9 & 0.004 & 15 & 0.003 & 15 & 0.004 & 16 \\
\hline $\mathrm{D}$ & Electricity, gas and steam & 0.012 & 7 & 0.012 & 7 & 0.013 & 8 & 0.006 & 10 & 0.005 & 11 & 0.007 & 10 \\
\hline $\mathrm{E}$ & Water, waste disposal and recycling services & 0.002 & 23 & 0.002 & 23 & 0.002 & 24 & 0.002 & 22 & 0.002 & 22 & 0.002 & 22 \\
\hline $\mathrm{F}$ & Construction & 0.001 & 27 & 0.001 & 28 & 0.001 & 28 & 0.001 & 26 & 0.001 & 27 & 0.001 & 28 \\
\hline G & Wholesale and retail trade services & 0.026 & 2 & 0.027 & 1 & 0.028 & 1 & 0.013 & 5 & 0.012 & 5 & 0.014 & 6 \\
\hline $\mathrm{H}$ & Transportation services & 0.016 & 6 & 0.017 & 6 & 0.017 & 6 & 0.008 & 7 & 0.008 & 7 & 0.008 & 8 \\
\hline $\mathrm{I}$ & Accommodation and food services & 0.008 & 9 & 0.008 & 9 & 0.008 & 10 & 0.010 & 6 & 0.009 & 6 & 0.011 & 7 \\
\hline $\mathrm{J}$ & $\begin{array}{l}\text { Information and communication/broadcasting and newspaper } \\
\text { and publishing }\end{array}$ & 0.006 & 11 & 0.006 & 11 & 0.006 & 12 & 0.038 & 2 & 0.041 & 1 & 0.035 & 4 \\
\hline $\mathrm{K}$ & ()/insurance/banking/() & & & 0.002 & 24 & 0.017 & 7 & & & 0.001 & 23 & 0.037 & 3 \\
\hline $\mathrm{L}$ & Real estate services & 0.019 & 4 & 0.017 & 5 & 0.018 & 4 & 0.033 & 3 & 0.029 & 3 & 0.043 & 2 \\
\hline $\mathrm{M}$ & Professional, scientific and technical services & 0.028 & 1 & 0.027 & 2 & 0.028 & 2 & 0.024 & 4 & 0.023 & 4 & 0.027 & 5 \\
\hline $\mathrm{N}$ & Business services & & & & & & & 0.042 & 1 & 0.038 & 2 & 0.048 & 1 \\
\hline $\mathrm{O}$ & Public administration, defense and, social security & 0.000 & 30 & 0.000 & 31 & 0.000 & 31 & 0.000 & 31 & 0.000 & 32 & 0.000 & 32 \\
\hline $\mathrm{P}$ & Education services & 0.001 & 29 & 0.001 & 30 & 0.001 & 30 & 0.001 & 23 & 0.001 & 25 & 0.002 & 24 \\
\hline $\mathrm{Q}$ & Health and social services & 0.002 & 25 & 0.002 & 26 & 0.002 & 26 & 0.002 & 18 & 0.002 & 20 & 0.003 & 19 \\
\hline $\mathrm{R}$ & Arts, sports and leisure services & 0.002 & 24 & 0.002 & 25 & 0.002 & 25 & 0.002 & 21 & 0.002 & 21 & 0.002 & 21 \\
\hline \multirow[t]{4}{*}{ S } & Other services & 0.003 & 18 & 0.003 & 19 & 0.004 & 20 & 0.003 & 16 & 0.003 & 17 & 0.005 & 15 \\
\hline & Indirect effect & 0.224 & $32.5 \%$ & 0.230 & $32.8 \%$ & 0.257 & $37.1 \%$ & 0.235 & $29.2 \%$ & 0.221 & $24.9 \%$ & 0.301 & $40.5 \%$ \\
\hline & Direct effect & 0.465 & $67.4 \%$ & 0.472 & $67.2 \%$ & 0.436 & $63.0 \%$ & 0.571 & $70.8 \%$ & 0.667 & $75.0 \%$ & 0.442 & $59.5 \%$ \\
\hline & Total effect & 0.689 & $100.0 \%$ & 0.702 & $100.0 \%$ & 0.692 & $100.0 \%$ & 0.806 & $100.0 \%$ & 0.889 & $100.0 \%$ & 0.743 & $100.0 \%$ \\
\hline
\end{tabular}


For the value-added inducing effect, the financial industry has better performance than the fintech industry. Figure 3 represents a detailed understanding of the direct and indirect effects. The financial industry has a strong value-added inducing effect for both the direct and indirect effects, except in the banking sector. In the banking sector-the core of the financial industry-fintech has an indirect value-added inducing effect amounting to 0.230 , with the financial industry trailing marginally at 0.221. Thus, the fintech industry also has a prominent role in transforming the banking sector for the fourth industrial revolution. The figure clearly shows that the portion of fintech's indirect effect on the value-added inducing effect accounts for 32.5 percent, higher than that of the financial industry (29.2 percent). Thus, fintech is still a strong prompter for transformation of all industries.

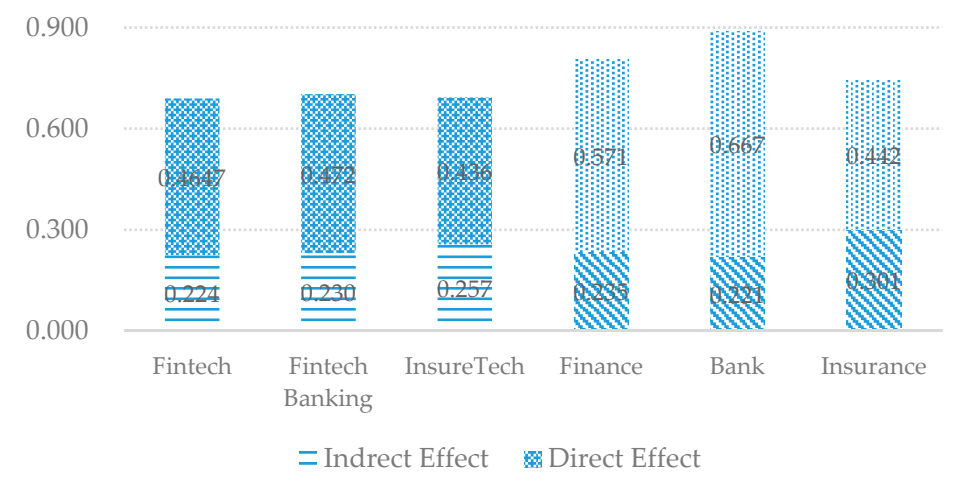

Figure 3. Value-Added Inducing Effects.

Table 9 reports the indirect value-added inducing effect for all other industries nationwide with respect to the fintech and financial industries. Overall, the financial industry has a strong effect on the tertiary service industry (75.6 percent). The fintech industry affects the secondary manufacturing industry (41.3 percent) at a higher rate compared with the financial industry (19.6 percent). Thus, the financial industry affects selective concentration on service industries, whereas fintech exhibits more diverseness and equitability.

Table 9. Rate of Value-Added Inducing Effects.

\begin{tabular}{|c|c|c|c|c|c|c|c|c|c|c|c|c|}
\hline \multirow[b]{2}{*}{ Primary industry } & \multicolumn{2}{|c|}{ Fintech } & \multicolumn{2}{|c|}{ Fintech Banking } & \multicolumn{2}{|c|}{ InsureTech } & \multicolumn{2}{|c|}{ Finance } & \multicolumn{2}{|c|}{ Bank } & \multicolumn{2}{|c|}{ Insurance } \\
\hline & 0.021 & $9.4 \%$ & 0.022 & $9.5 \%$ & 0.023 & $9.0 \%$ & 0.011 & $4.8 \%$ & 0.010 & $4.6 \%$ & 0.013 & $4.3 \%$ \\
\hline Secondary industry & 0.093 & $41.3 \%$ & 0.097 & $42.1 \%$ & 0.102 & $39.6 \%$ & 0.046 & $19.6 \%$ & 0.042 & $19.1 \%$ & 0.052 & $17.3 \%$ \\
\hline
\end{tabular}

\subsection{Supply-Driven Model and Supply Shortage Effect}

To be feasible as a platform of the national economy, the fintech industry should exhibit a resilient effect even when there exists a negative shock of the supply shortage effect. Here, the supply shortage effect implies the degree to which other industries should decrease production for a demand shortage to decrease one more unit of production when evaluating the subject subsector.

Table 10 reports the results of the supply shortage effect. With a unit decrease of production, fintech induced a value reduction of 0.657 from all other industries' reduced production. In the fintech industry, the fintech banking subsector induced a 0.715 decrease and fintech insurance induced a $\$ 0.614$ decrease. Moreover, the financial industry induced a $\$ 1.011$ value reduction overall, whereas the banking subsector induced a 1.422 reduction, which is the highest reduction from the supply shortage effect. Note that the difference is clearer when we compare each subsector rather than only fintech. The insurance industry has a stronger supply shortage effect for fintech, whereas the banking subsector has a far weaker effect. This sub-sectoral difference will grow further as most financial sectors transform into the fintech industry. 
Table 10. Results of the Supply Shortage Effects.

\begin{tabular}{|c|c|c|c|c|c|c|c|c|c|c|c|c|c|}
\hline & \multirow[t]{2}{*}{ Supply Shortage Effects } & \multicolumn{2}{|c|}{ Fintech } & \multicolumn{2}{|c|}{ Fintech Banking } & \multicolumn{2}{|c|}{ InsureTech } & \multicolumn{2}{|c|}{ Finance } & \multicolumn{2}{|c|}{ Bank } & \multicolumn{2}{|c|}{ Insurance } \\
\hline & & Effects & Rank & Effects & Rank & Effects & Rank & Effects & Rank & Effects & Rank & Effects & Rank \\
\hline A & Agriculture, forestry and fisheries products & 0.008 & 23 & 0.009 & 24 & 0.007 & 26 & 0.016 & 22 & 0.021 & 23 & 0.005 & 24 \\
\hline B & Minerals & 0.001 & 30 & 0.001 & 31 & 0.001 & 31 & 0.002 & 31 & 0.003 & 32 & 0.001 & 32 \\
\hline $\mathrm{C} 01$ & Food and beverage & 0.039 & 5 & 0.040 & 5 & 0.035 & 5 & 0.052 & 7 & 0.066 & 8 & 0.024 & 8 \\
\hline $\mathrm{C} 02$ & Textiles and leather products & 0.006 & 26 & 0.007 & 27 & 0.006 & 27 & 0.009 & 25 & 0.012 & 26 & 0.004 & 26 \\
\hline $\mathrm{C} 03$ & Wood and paper and printing & 0.002 & 29 & 0.002 & 30 & 0.002 & 30 & 0.003 & 30 & 0.004 & 31 & 0.002 & 31 \\
\hline C04 & Coal and petroleum products & 0.021 & 12 & 0.022 & 13 & 0.019 & 11 & 0.026 & 17 & 0.035 & 16 & 0.011 & 19 \\
\hline $\mathrm{C} 05$ & Chemicals & 0.057 & 4 & 0.060 & 4 & 0.054 & 4 & 0.062 & 5 & 0.080 & 6 & 0.029 & 5 \\
\hline $\mathrm{C} 06$ & Nonmetallic mineral products & 0.008 & 24 & 0.009 & 25 & 0.008 & 24 & 0.011 & 24 & 0.014 & 25 & 0.005 & 25 \\
\hline $\mathrm{C} 07$ & Primary metal products & 0.031 & 7 & 0.033 & 7 & 0.028 & 7 & 0.040 & 9 & 0.053 & 10 & 0.017 & 15 \\
\hline $\mathrm{C} 08$ & Fabricated metal products & 0.020 & 13 & 0.021 & 14 & 0.018 & 13 & 0.027 & 16 & 0.034 & 17 & 0.013 & 16 \\
\hline $\mathrm{C} 09$ & Computers and electronics/precision instruments & 0.012 & 19 & 0.012 & 20 & 0.012 & 18 & 0.069 & 4 & 0.085 & 5 & 0.039 & 2 \\
\hline $\mathrm{C} 10$ & Electrical equipment & 0.029 & 9 & 0.031 & 9 & 0.030 & 6 & 0.024 & 19 & 0.030 & 20 & 0.013 & 17 \\
\hline C11 & Machinery and equipment & 0.030 & 8 & 0.031 & 8 & 0.028 & 8 & 0.038 & 10 & 0.048 & 11 & 0.019 & 11 \\
\hline $\mathrm{C} 12$ & Transportation equipment & 0.072 & 1 & 0.076 & 1 & 0.069 & 1 & 0.076 & 3 & 0.099 & 3 & 0.034 & 3 \\
\hline C13 & Other manufacturing products & 0.005 & 27 & 0.005 & 28 & 0.004 & 28 & 0.005 & 28 & 0.007 & 29 & 0.003 & 30 \\
\hline $\mathrm{C} 14$ & Manufacturing and industrial equipment repairs & 0.011 & 20 & 0.012 & 21 & 0.011 & 21 & 0.012 & 23 & 0.015 & 24 & 0.007 & 23 \\
\hline $\mathrm{D}$ & Electricity, gas and steam & 0.015 & 17 & 0.016 & 18 & 0.013 & 16 & 0.024 & 18 & 0.033 & 18 & 0.008 & 20 \\
\hline E & Water, waste disposal and recycling services & 0.004 & 28 & 0.004 & 29 & 0.003 & 29 & 0.005 & 29 & 0.006 & 30 & 0.004 & 27 \\
\hline $\mathrm{F}$ & Construction & 0.058 & 3 & 0.060 & 3 & 0.056 & 2 & 0.060 & 6 & 0.075 & 7 & 0.033 & 4 \\
\hline G & Wholesale and retail trade services & 0.059 & 2 & 0.061 & 2 & 0.055 & 3 & 0.077 & 2 & 0.093 & 4 & 0.046 & 1 \\
\hline $\mathrm{H}$ & Transportation services & 0.025 & 10 & 0.026 & 11 & 0.023 & 9 & 0.034 & 12 & 0.043 & 13 & 0.018 & 13 \\
\hline I & Accommodation and food services & 0.023 & 11 & 0.024 & 12 & 0.020 & 10 & 0.037 & 11 & 0.047 & 12 & 0.018 & 12 \\
\hline $\mathrm{J}$ & $\begin{array}{c}\text { Information and communication/broadcasting and newspaper } \\
\text { and publishing }\end{array}$ & 0.010 & 22 & 0.011 & 23 & 0.010 & 23 & 0.027 & 15 & 0.032 & 19 & 0.018 & 14 \\
\hline K & ()/insurance/banking/() & & & 0.027 & 10 & 0.018 & 12 & & & 0.119 & 2 & 0.027 & 6 \\
\hline $\mathrm{L}$ & Real estate services & 0.032 & 6 & 0.034 & 6 & 0.013 & 17 & 0.114 & 1 & 0.163 & 1 & 0.019 & 10 \\
\hline M & Professional, scientific and technical services & 0.011 & 21 & 0.011 & 22 & 0.011 & 22 & 0.048 & 8 & 0.060 & 9 & 0.025 & 7 \\
\hline $\mathrm{N}$ & Business services & & & & & & & 0.008 & 27 & 0.010 & 28 & 0.003 & 29 \\
\hline $\mathrm{O}$ & Public administration, defense and social security & 0.016 & 15 & 0.016 & 17 & 0.012 & 20 & 0.030 & 13 & 0.041 & 14 & 0.011 & 18 \\
\hline $\mathrm{P}$ & Education services & 0.016 & 16 & 0.016 & 16 & 0.014 & 15 & 0.020 & 20 & 0.026 & 21 & 0.007 & 21 \\
\hline $\mathrm{Q}$ & Health and social services & 0.017 & 14 & 0.017 & 15 & 0.014 & 14 & 0.030 & 14 & 0.035 & 15 & 0.021 & 9 \\
\hline $\mathrm{R}$ & Arts, sports and leisure services & 0.007 & 25 & 0.007 & 26 & 0.007 & 25 & 0.008 & 26 & 0.010 & 27 & 0.003 & 28 \\
\hline \multirow[t]{2}{*}{ S } & Other services & 0.013 & 18 & 0.014 & 19 & 0.012 & 19 & 0.018 & 21 & 0.024 & 22 & 0.007 & 22 \\
\hline & Indirect effect & 0.657 & & 0.715 & & 0.614 & & 1.011 & & 1.422 & & 0.494 & \\
\hline
\end{tabular}


Regarding the supply shortage effect on other industries, the fintech industry has a stronger effect on "transportation equipment" (C12), whereas the financial industry has a stronger effect on "real estate services" (L). Overall, the fintech industry has a highly varying supply shortage effect on each subsector, with the most severe on manufacturing industries. Contrariwise, the financial industry does not exhibit such a trend across all industries but shows severe reduction for the service-oriented industries.

Table 11 reports the results of the indirect supply shortage effect on other industries for both the fintech and financial industries. Overall, the fintech industry strongly affects the manufacturing industry (63.8 percent), followed by the service sector (34.8 percent). The financial industry affects the manufacturing industry (53.7 percent) strongly. Thus, the service sector is not differentiated with respect to the fintech and financial supply shortage effects, though we find a stronger supply shortage effect on the manufacturing industry by the fintech industry's supply shortage effect. The primary industry, such as agriculture, does not indicate any serious negative supply shortage effect, because the fintech and financial industries here accounted for only 1.4 percent and 1.7 percent, respectively.

Table 11. Rate of Supply Shortage Effects.

\begin{tabular}{ccccccccccccc}
\hline & \multicolumn{2}{c}{ Fintech } & \multicolumn{2}{c}{ Fintech Banking } & \multicolumn{2}{c}{ InsureTech } & \multicolumn{2}{c}{ Finance } & \multicolumn{2}{c}{ Bank } & Insurance \\
\hline Primary Industry & 0.010 & $1.4 \%$ & 0.010 & $1.4 \%$ & 0.008 & $1.2 \%$ & 0.018 & $1.7 \%$ & 0.024 & $1.7 \%$ & 0.006 & $1.2 \%$ \\
Secondary industry & 0.419 & $63.8 \%$ & 0.439 & $61.5 \%$ & 0.397 & $64.6 \%$ & 0.542 & $53.7 \%$ & 0.694 & $48.8 \%$ & 0.264 & $53.4 \%$ \\
Tertiary industry & 0.229 & $34.8 \%$ & 0.265 & $37.1 \%$ & 0.210 & $34.2 \%$ & 0.451 & $44.6 \%$ & 0.705 & $49.6 \%$ & 0.224 & $45.4 \%$ \\
\hline
\end{tabular}

\subsection{Industry Linkage Effect}

To analyze the feasibility of the fintech industry as a platform for sustainable development, we examine the interindustry linkage effect in the final stage. Table 12 reports the empirical results of this evaluation.

Table 12. Results of the Interindustry Analysis.

\begin{tabular}{ccccc}
\hline & Forward Linkage Effect & Rank & Background Linkage Effect & Rank \\
\hline Fintech & 3.052 & $1 / 31$ & 0.890 & $22 / 31$ \\
Fintech banking & 3.160 & $1 / 32$ & 0.894 & $22 / 32$ \\
Insuretech & 2.685 & $1 / 32$ & 0.938 & $20 / 32$ \\
Finance & 1.101 & $11 / 32$ & 0.722 & $28 / 32$ \\
Bank & 1.077 & $13 / 33$ & 0.665 & $31 / 33$ \\
Insurance & 0.657 & $24 / 33$ & 0.818 & $28 / 33$ \\
\hline
\end{tabular}

The industry linkage effect comprises the forward and background linkage effects. The former is measured by the sensitivity coefficient and is defined as the outputs of the concerned subject subsector used as the inputs of the other industries. The former is measured by the influence coefficient-the produced outputs of all other industries for the concerned subject subsector used as the inputs to increase one unit of output.

There are four types of industries based on this linkage effect:

- If all the forward and background linkage effects are higher (than 1), the industry falls under intermediate demand-oriented manufacturing.

- If the forward linkage effect is higher than the background linkage effect, then the industry is intermediate demand-oriented primitive.

- The final demand-oriented manufacturing industry has weak forward linkage and strong background linkage effects.

- Finally, the final demand-oriented primitive industry has weak forward and background linkage effects [41].

Table 12 reports the results of the interindustry linkage effect. Except for the insurance subsector, all the other five subsectors measure a forward linkage effect valued over 1 and a background linkage 
effect lower than 1 . Thus, these industries are intermediate demand-oriented primitive industries. Nonetheless, the fintech industry has a stronger forward linkage effect for all subsectors compared with the financial industry. That is, the fintech industry can more effectively promote all other industries.

\section{Conclusions}

The fourth industrial revolution is one of the most important trends, indicating a paradigm shift from productivity-oriented competition to value creation based on network management of innovation [43]. Innovation herein entails creative destruction of the legacy system, which is also the foundation of the fourth industrial revolution.

The fourth industrial revolution has a powerful effect in transforming all nationwide economic structures and business models thereof. This makes fintech a critical feature of this revolution because it also promotes the transformation of all legacy systems across the national economy.

In the literature, there are varying arguments on fintech's feasibility as a prompter for qualitatively transforming the economic infrastructure into an advanced one. Most of these discussions have dealt with fintech as an expansion of the ordinary or traditional financial industry. In our research, we assumed the fintech industry as having a wider and more inclusive role in transforming all industries toward value creation networking. This networking becomes the platform for sustainable innovation of the national economy because it implies that all participants of the fintech revolution shall voluntarily create and share new values [44]. We thus employed an interindustry analysis to examine the feasibility of fintech in this regard and found that it does create enhanced values for both the forward and background linked industries.

We summarize our contributions in the form of important implications and suggestions below:

First, the production inducing effects in DDM, SDM and industry linkage effects show that fintech is supportive for all other industries, especially manufacturing industries, in terms of inducing more production and supply, whereas the effect of the ordinary financial industry is limited on the financial subsector and its surrounding service sectors. The fintech industry has strong industry linkage effects for forward and background industries, implying that all participants through collaborative networks of innovation could realize a sustainable fintech industry.

Second, the fintech industry has positive and even interindustry linkage effects on all industries nationwide. Thus, its role is not only limited to the extension of the financial industry. In the production inducing effect, the financial industry affected the primary industry at a rate of 4.3 percent, the secondary industry at 31.7 percent and the tertiary industry at 64 percent, whereas these percentages were respectively 7.0 percent, 55.8 and 37.3 percent for the fintech industry (e.g., Table 8) Thus, the fintech industry is not a part of the financial industry per se but could be a platform or prompter to induce almost all industries evenly.

We also found that the fintech industry could be an effective prompter for sustainable development of the national economy. This is because its indirect and direct effects allow for diverse uses of financial technologies in financial/monetary-related activities as well as complementary automatic synchronized economic activities. Indeed, under fintech, such activities can be executed with higher security through technologies such as blockchain. This creates an advanced, creative smart infrastructure and surrounding ecosystem. To maintain circular innovation, fintech can harmonize technological innovation and organizational transformation for all participants $[11,30,31]$.

However, the direct and indirect effects of the value added, inducing effect of DDM are lower in the fintech industry than in the financial industry. These results imply the limitations of the current fintech industry in Korea. In this regard, South Korean fintech policy has a positive system of regulation, as stated earlier. Thus, a new startup, including any fintech startup, has serious psychological and practical barriers. In China, new and innovative startups are supported by Alipay and other e-payments within the fintech industry. Such developments are possible at least in the initial stages because of China's negative regulation system. Therefore, the Korean government should also change its political paradigm from the current positive regulation to newer negative regulations. 
Despite the Korean government's promotion of new startups, especially in the fintech industry, through some deregulation, the current policies still lead to invisible and unexpected regulations under the broader positive system. Thus, deregulation has only limited scope in supporting fintech innovation. Instead, developing economies should radically reform their regulatory system to allow fintech to become a strong prompter. Such policies should be the global norm. The fintech industry is expected to create greater conflicts among interest groups, especially from traditional, substitutable companies. Thus, governments should seek to resolve such conflicts proactively by promoting innovation as universally beneficial in the long term.

This study confirms that the fintech industry contributes to the growth promotion of many other industries unlikely by the traditional financial industry, as an innovation platform for all industries for sustainable growth. Nevertheless, this study has the following limitations.

First, this study has limitations using the data from 2015. Therefore, it is necessary to prove the feasibility as an innovation platform of the fintech industry by comparing the differences with this study in future studies. In addition, as seen in the literature, fintech has a different value depending on how it is used in various industries. However, this study only considers the economic aspects, so it is not possible to propose a way to contribute to the added values and economic growth promotion, through various applications of fintech. Therefore, in the future research, it is necessary to conduct research that can make strategic proposals to individual companies that want to apply it through research on various applications of fintech. Such a study would be a practical way to promote the sustainable growth of all industries.

Author Contributions: The authors contributed to each part of the paper by: conceptualization, Y.C.; methodology, Y.J.S.; software, Y.C.; validation, Y.C.; formal analysis, Y.C.; investigation, Y.J.S; resources and data curation, Y.J.S.; writing—original draft preparation, Y.C.; writing—review and editing, Y.C.; supervision, Y.J.S.; project administration, Y.J.S.; funding acquisition.

Funding: Inha University Research Fund supported this work.

Conflicts of Interest: The authors declare no conflict of interest.

\section{References}

1. Basole, R.C.; Patel, S.S. Transformation through unbundling: Visualizing the global FinTech ecosystem. Serv. Sci. 2018, 10, 379-396. [CrossRef]

2. Oxford Dictionary. Available online: http://www.oxforddictionaries.com/it/definizione/inglese/fintech (accessed on 20 August 2016).

3. Sanicola, L. What is FinTech? Huffington Post. Available online: https://www.huffpost.com/entry/what-isfintech_b_58a20d80e4b0cd37efcfebaa (accessed on 5 August 2019).

4. Lee, I.; Shin, Y.J. Fintech: Ecosystem, business models, investment decisions and challenges. Bus. Horiz. 2018, 61, 35-46. [CrossRef]

5. Philippon, T. The Fintech Opportunity (No. w22476); National Bureau of Economic Research: Cambridge, MA, USA, 2016.

6. CBinsights. Fintech Trends to Watch in 2019. CB Insights. Available online: https://www.cbinsights.com/ research/report/fintech-trends-2019/ (accessed on 20 July 2019).

7. PWC. Pwc Global FinTech Survey 2017. Available online: https://www.pwc.com/gx/en/industries/financialservices/assets/pwc-global-fintech-report-2017.pdf (accessed on 20 July 2019).

8. KPMG. The Plus of Fintech 2018. Available online: https://assets.kpmg/content/dam/kpmg/xx/pdf/2019/02/ the-pulse-of-fintech-2018.pdf (accessed on 20 July 2019).

9. Arner, D.W.; Barberis, J.; Buckley, R.P. The evolution of Fintech: A new post-crisis paradigm. Geo. J. Int. L. 2015, 47, 1271. [CrossRef]

10. Gomber, P.; Kauffman, R.J.; Parker, C.; Weber, B.W. On the fintech revolution: Interpreting the forces of innovation, disruption and transformation in financial services. J. Manag. Inform. Syst. 2018, 35, 220-265. [CrossRef]

11. KPMG. Fintech 100-Leading Global Fintech Innovators Report 2015. Available online: https://assets.kpmg/ content/dam/kpmg/pdf/2015/12/fintech-100-leading-innovators-2015.pdf (accessed on 20 July 2019). 
12. Alt, R.; Beck, R.; Smits, M.T. FinTech and the transformation of the financial industry. Electron. Mark. 2018, 28, 235-243. [CrossRef]

13. Taylor, T.A. On-demand service platforms. Manuf. Serv. Op. Manag. 2018, 20, 704-720. [CrossRef]

14. EY. The Future of FinTech and Financial Services What's the Next Big Bet? EY: Singapore, 2018.

15. Sundararajan, A. The Sharing Economy: The end of Employment and the Rise of Crowd-Based Capitalism; Mit Press: Cambridge, MA, USA, 2016.

16. Zavolokina, L.; Dolata, M.; Schwabe, G. FinTech-What's in a Name? In Proceedings of the ICIS Digital Innovation at the Crossroads Conference, Dublin, Ireland, 14 December 2016.

17. Dorfleitner, G.; Hornuf, L.; Schmitt, M.; Weber, M. Definition of FinTech and description of the FinTech industry. In FinTech in Germany; Springer: Cham, Switzerland, 2017; pp. 5-10.

18. Chishti, S.; Barberis, J. The FinTech Book: The Financial Technology Handbook for Investors, Entrepreneurs and Visionaries; John Wiley \& Sons: Hoboken, NJ, USA, 2016.

19. Micu, I.; Micu, A. Financial technology (Fintech) and its implementation on the Romanian non-banking capital market. SEA Pract. Appl. Sci. 2016, 11, 379-384.

20. Mackenzie, A. The Fintech Revolution; London Business School Review: London, UK, 2015; Volume 26, pp. 50-53.

21. Chiu, I.H. Fintech and disruptive business models in financial products, intermediation and markets-policy implications for financial regulators. J. Tech. L. Pol'y 2016, 21, 55.

22. Leong, C.; Tan, B.; Xiao, X.; Tan, F.T.C.; Sun, Y. Nurturing a FinTech ecosystem: The case of a youth microloan startup in China. Int. J. Inform. Manag. 2017, 37, 92-97. [CrossRef]

23. Kim, Y.; Park, Y.J.; Choi, J.; Yeon, J. The adoption of mobile payment services for "Fintech". Int. J. Appl. Eng. Res. 2016, 11, 1058-1061.

24. Chuang, L.M.; Liu, C.C.; Kao, H.K. The adoption of fintech service: TAM perspective. Int. J. Manag. Adm. Sci. 2016, 3, 1-15.

25. Chang, Y.; Wong, S.F.; Lee, H.; Jeong, S.P. What motivates Chinese consumers to adopt FinTech services: A regulatory focus theory. In Proceedings of the 18th Annual International Conference on Electronic Commerce: E-Commerce in Smart Connected World ACM, Suwon, Korea, 17-19 August 2016; p. 40.

26. Lim, S.H.; Kim, D.J.; Hur, Y.; Park, K. An Empirical study of the impacts of perceived security and knowledge on continuous intention to use mobile fintech payment services. Int. J. Hum. Comput. Interact. 2019, 35, 886-898. [CrossRef]

27. Porras-Gonzalez, E.R.; Martín-Martín, J.M.; Guaita-Martínez, J.M. A critical analysis of the advantages brought by blockchain technology to the global economy. Int. J. Intellect. Prop. Manag. 2019, 9, 166-184. [CrossRef]

28. Korea Financial Supervisory Service. FinTech Key Trends and Implications. Available online: http: $/ /$ www.fss.or.kr/fss/kr/promo/bodobbs_view.jsp?s_kind=title\&s_title $=\& p a g e=25 \&$ seqno $=21343$ (accessed on 10 July 2019).

29. Choi, Y. The Asian values of $\mathrm{Gu}^{-}$anxì as an economic model for transition toward green growth. Sustainability 2018, 10, 2150. [CrossRef]

30. Teece, D.J. Profiting from technological innovation: Implications for integration, collaboration, licensing and public policy. Res. Policy 1986, 15, 286-305. [CrossRef]

31. Christenson, C. The Innovator's Dilemma; Harvard Business School Press: Cambridge, MA, USA, 1995.

32. Bower, J.L.; Christensen, C.M. Disruptive Technologies: Catching the Wave; Harvard Business Review: Boston, MA, USA, 1995; pp. 43-53.

33. Shin, Y.J.; Choi, S.W. Effects of the IT service industry on Korean economy: Using inter industry analysis. Int. J. Adv. Comput. Technol. 2013, 5, 360-372.

34. Shin, Y.J.; Yim, M.S. The Role of the IT Industry in the Korean economy: An inter-industry analysis. Int. J. Appl. Eng. Res. 2015, 10, 123-134.

35. Kim, K.; Jung, J.K.; Choi, J. Impact of the smart city industry on the Korean national economy: Input-output analysis. Sustainability 2016, 8, 649. [CrossRef]

36. Kim, Y.J.; Kim, C.Y.; Shin, Y.J. The effects of ubiquitous healthcare service on the south Korean Economy: Using input-output analysis. Inform. Syst. Front. 2017, 19, 1149-1160. [CrossRef]

37. Shin, Y.J. A comparative study on the employment creation effect of FinTech industry in Korea and USA. J. Digit. Converg. 2018, 16, 185-195. 
38. Miller, R.E.; Blair, P.D. Input-Output Analysis: Foundations and Extensions; Cambridge University Press: Cambridge, UK, 2009.

39. Xing, W.; Ye, X.; Kui, L. Measuring convergence of China's ICT industry: An input-output analysis. Telecommun. Policy 2011, 35, 301-313. [CrossRef]

40. Rohman, I.K. The globalization and stagnation of the ICT sectors in European countries: An input-output analysis. Telecommun. Policy 2013, 37, 387-399. [CrossRef]

41. The Bank of Korea. Input-Output Statistics; The Bank of Korea: Seoul, South Korea, 2014.

42. Yoo, S.H.; Yoo, T.H. The role of the nuclear power generation in the Korean national economy: An input-output analysis. Prog. Nucl. Energy 2009, 51, 86-92. [CrossRef]

43. Korea Financial Services Commission Press Release. Promotion of Financing Company Financing Investment. Available online: http://www.korea.kr/briefing/pressReleaseView.do?newsId=156305807 (accessed on 27 November 2018).

44. Choi, Y. Challenges of Asian models and values for sustainable development. Sustainability 2019, 11, 1497. [CrossRef]

(C) 2019 by the authors. Licensee MDPI, Basel, Switzerland. This article is an open access article distributed under the terms and conditions of the Creative Commons Attribution (CC BY) license (http://creativecommons.org/licenses/by/4.0/). 